Scholedge International Journal of Multidisciplinary \& Allied Studies ISSN 2394-336X, Vol.04, Issue 06 (2017) Pg 36-49.

DOI: $10.19085 /$ journal.sijmas040601
Published by: Scholedge R\&D Center

www.theSCHOLEDGE.org

Email: editorial@thescholedge.org

(O) Publisher

\title{
SMART CITIES AND SUSTAINABLE URBANISM: A STUDY FROM POLICY AND DESIGN PERSPECTIVE
}

\author{
Mihir Bholey \\ Senior Faculty, Interdisciplinary Design Studies, National Institute of Design, Ahmedabad, India.
}

\begin{abstract}
This paper examines India's foray into building hundred smart cities from multiple perspectives viz. urban challenges, urban policies, sustainable urbanism, emerging global models and design and technology intervention. It also evaluates the relative challenges of building new smart cities like Masdar or Songdo and applying smart interventions to retrofit the aging and ailing urban infrastructure of the existing Indian cities. Based on the data from the secondary sources it examines the priority areas and the possibilities of making smart intervention through use of appropriate technology and design. While doing so, it brings into discussion India's urban challenges and its policy of urban development over the years besides the recurring development deficit. Today, Indian cities are faced with huge infrastructure deficit which reflects in their performance and service delivery. The imperative to ensure urban rejuvenation now reflects in the recent policy of creating hundred smart cities in India. This paper also discusses howtechnology and design interventions at appropriate levels canaugment urban infrastructure and make a sustainable urban eco-system called smart city.
\end{abstract}

Keywords: smart city, urbanization, urban policy, sustainable urbanism, design, technology

\section{Introduction}

India is among one of world's few oldest civilizations where planned urbanization existed even in the early phase of their history. Extended thoroughfares with north-south alignment, straight configuration of the house walls, drainage network, water chutes, manholes to clean slush, great bath, citadel etc. which marked the cities of Indus valley civilization were surely the models of smart cities way back in 3300 BC.Now in the $21^{\text {st }}$ century India is once again exploring ways and means to rejuvenate its overstretched urban set up with smart interventions. The idea finds expression in one of India's most ambititous flagship policies of building 100 smart cities applying smart interventions in terms of technology and design in the existing cities. Decades of hiatus between policy and urban development is being reevaluated. There is an obvious correlation between urban dysfunction over the years and the policy bias. Policymakers in India for a long time have had a rural bias for their own justified reasons. The two most imminent were the concern for India's huge rural population and its dependence on agrarian economy which provided rural population the means of economic sustenance.

In the initial years of independence, close to 82 percent of India's population was rural. This was a kind of moral justification to follow the spirit Gram Swaraj - the Gandhian model of self-reliant villages based on equitable and non-violent order. It worked as a guiding principle for the policymakers for successive years and to an extent reflected in the policies of rural development in a rather subtle manner. However, despite Gandhi's socio-economic vision for rural sustainability and the need to strengthen and empower the village community, urban India keeps growing. Though it ranks among the least urbanized countries where urbanization increased at the rate of 13 percentage points only in fifty years between 1951-2001. Nevertheless, it has the second largest urban population in the world (Rai \& Singh, 2010). India not only experienced exponential growth in terms of size, demography and economic development but also attracted huge rural migration. In fact, it went through the same cycle of development wherein the share of agriculture to GDP often declines and industrial and service sectors dominate the 
scene. While the concentration of capital, skill and other resources in cities precipitated economic growth, the lack of corresponding investment in infrastructure and planning made the Indian cities suffer from urban decay.

Of late, the model of globalization-led economic development has also transformed the cities into the growth engines of economy. India is no exception. Contribution of Indian cities to GDP is estimated to be $58 \%$. It's expected to become $70 \%$ by 2030 . With nearly 377 million Indians comprising $31.14 \%$ of the country's population now living in urban areas (as per 2011 census), the urban population in India is growing at the rate of $2.76 \%$ per annum. If it continues growing at the same rate, by 2031 the urban population will touch 600 million mark (40\%) and 850 million by 2051 which will be $50 \%$ of its total population. Surely, this demography will throw major challenges before the policymakers, urban planners, architects, engineers, designers and the rest.

\section{India's Urban Challenges}

India's urban demography is changing at a fast pace which is contributing to the urban infrastructure deficit. Paul (2010) identifies weaknesses at three fronts namely: (1) infrastructure, (2) finance and (3) governance responsible for the urban problems.

\section{Diagram: 1 India's Urban Challenges}

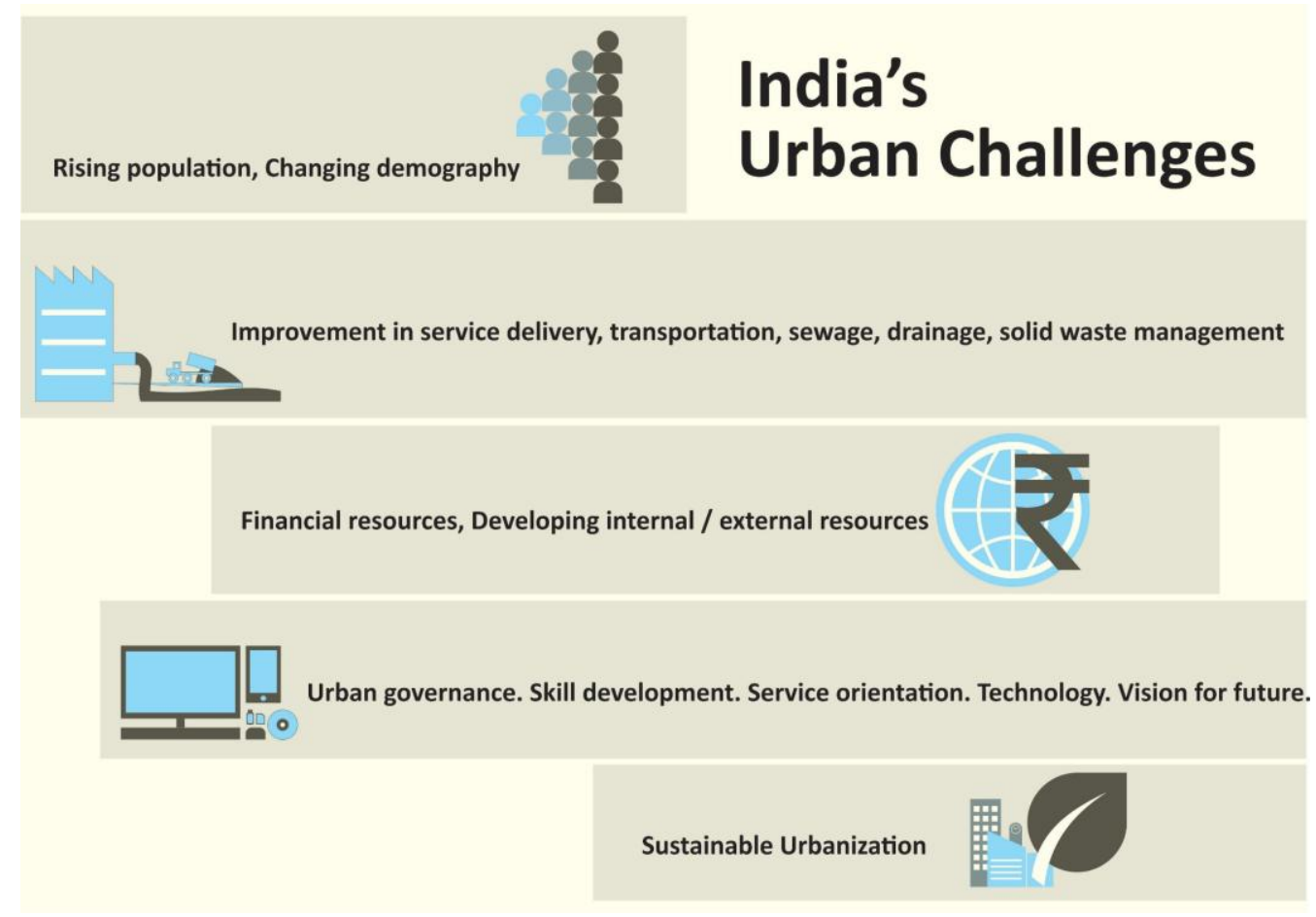

\section{India's Urban Challenges. Conceptual Model: Mihir Bholey}

The country faces the challenge of providing its 377 million urban population (and growing) safe water, sanitation, housing, healthcare, energy, services of waste management etc. as the basic requirement. However, from the smart city perspective these services need to be augmented with smart interventions in the form of ICT infrastructure, technology and design as well .Like everywhere else, cities in India too have evolved. It's visible in its demography, system, design, infrastructure, management and so on. Marshall (2012) looks at urban evolution as "a continuous process that applies as much today as in the past. That is, evolutionary urbanism is not some rudimentary historic process that was supplanted by modern town planning." The challenges these evolution pose are humongous. 
The World Bank Report titled Leveraging Urbanization in India (2015), highlights that due to messy urbanization 65.5 million people live in urban slums and 13.7 percent urban population lived below poverty line. This poses a great challenge for urban inclusion. Ahluwalia and Mohanty (2014) blame it on the master planning and zoning regulations in Indian cities which has over the years neglected the need and aspiration of the low income group population for space. This is ironical because despite the apparent pro-poor policies of the successive governments, there is a stark deficit of proper housing for the urban which has resulted in the mushrooming of slums across all Indian cities particularly in the big ones. Bholey (2016) writes:

"The question inevitably arises - where is the gap, whether at the policy or at implementation level? A democratic constitution that India has, nurtures the ideal of social inclusion in words and spirit. Good governance and satisfactory service delivery are some of the basic expectations of the people from the government. However, converting spirit into action is often better said than done."

The PWC report (2015) on making smart and sustainable cities points out one of the biggest challenges for smart city which will redefine its very concept and approach. It refers to the Sustainable Development Goal (SDG) of the United Nations which will soon replace the Millennium Development Goal (MDG). The SDG has a focus on sustainable cities and communities. It recognizes the fact that globally cities occupy only 3 percent of earth's land but they're responsible for 60-80 percent of energy consumption and 75 percent of carbon emission. Besides, they're putting tremendous pressure on fresh water supplies, sewage, living environment, and public health. It sees a possibility of bringing efficiency gains, technological innovation and at the same time reduce energy consumption. (Sustainable Development Goals, UNO). So while India will be setting its own agenda and putting its own plans for smart cities into action, the SDG will shift the goal post. This will emerge as the new challenge for smart cities in India. However, striking a balance between the old and the new and the varied degree of socio-cultural diversity is another big challenge for urbanization in India. Shaw (2012) rightly points out:

"Urban built environment in India has been a product of the assimilation and hybridization of centuries of cultural contact with diverse influences.......characteristics of Indian urbanism in such a varied context and stretching across several millennia that mark this civilization is too huge a task...."

Indian cities differ from each other in terms of their social-cultural-economic and religious significance. That has made them evolve differently. For example, while Mumbai has remained India's commercial capital, Bengaluru has evolved as the IT capital. Both are metropolitan cities, yet both the cities demand different kinds of interventions to make them function properly. There're cities as old as Varanasi (or Banaras) and as new as Lavasa; one of the emerging smart cities in India. While the earlier is a perfect example of organic growth, the latter is probably the finest specimen of a city designed on drawing board and implemented on land.

\section{Urban Challenge: Sanitation}

For the densely populated Indian cities, sanitation is a big challenge. Most of the cities are still faced with basic problems of solid waste management, sewage and toilets. It's further complicated by large scale urban migration and the daily floating population coming to big and small cties. Planning Commission Approach to the $12^{\text {th }}$ Plan titled 'The Challenges of Urbanization in India' underscored the dispersed nature of urbanization in India. It pointed out the 'distributed nature of urban India having a diverse range of large and small cities which are unevenly spread across the nation. India may continue with this distributed model of urbanization because as the report writes: "this suits its federal structure and helps to ensure that migration flows aren't unbalanced toward any particular city or cities'. The report estimates that the demand for key services including water, transportation, sewage treatment, low income housing among other will increase five- to sevenfold in cities of every size and type in the years to come. There's also a huge deficit between the per capita expenditure on urban infrastructure estimated to be $\$ 17$ to the required $\$ 100$.

The Govt. of India Ministry of Urban Development 'Handbook of Urban Development' (2016) data reveals that the level of urbanization in India as a whole has increased from 25.7\% in 1991 to $27.82 \%$ in 200 and to 31.14\% in 2011. The data in the report further reveals the skewed ratio between India's urban sanitation demand and supply. Swachh Bharat Mission, (a clean India drive) launched by the govt. in 2014 has to achieve the target by 2019. It has to take care of individual household toilets, community toilets, public toilets, municipal solid waste management etc which 
is a daunting task. The urban sanitation problem in India is compounded due to the socio-economic factors and the infrastructure deficit. Besides that, the culture of general hygiene and cleanliness' is something often ignored by a large number of people and thus make all the sanitation effort by the government ineffective. The behavioural and attitudinal issues are being addressed by the awareness campaigns run by the government. The following tables (1\&2) depicting the bathing and drainage and toilet facility give us some idea about the infrastructure deficit.

Table-1: Bathing and Drainage Facilities in 2011 (The Handbook of Urban Statistic 2016)

\begin{tabular}{|c|c|c|c|c|c|}
\hline \multirow[b]{2}{*}{ S.No. } & \multirow[b]{2}{*}{ States/UTs } & \multicolumn{2}{|c|}{2001} & \multicolumn{2}{|c|}{2011} \\
\hline & & $\begin{array}{l}\text { Percentage of } \\
\text { HHs having } \\
\text { bathroom facility } \\
\text { within premises }\end{array}$ & $\begin{array}{l}\text { Percentage of } \\
\text { HHs having } \\
\text { Drainage facility }\end{array}$ & $\begin{array}{l}\text { Percentage of HHs } \\
\text { having bathing } \\
\text { facility within the } \\
\text { premises }\end{array}$ & $\begin{array}{l}\text { Percentage of } \\
\text { HHs having } \\
\text { drainage facility }\end{array}$ \\
\hline 1 & Andaman \& Nicobar Islands & 78.18 & 74.13 & 93.87 & 86.04 \\
\hline 2 & Andhra Pradesh & 78.48 & 82.29 & 92.61 & 88.26 \\
\hline 3 & Arunachal Pradesh & 53.93 & 63.26 & 80.65 & 66.21 \\
\hline 4 & Assam & 52.98 & 52.62 & 84.54 & 56.35 \\
\hline 5 & Bihar & 43.13 & 68.61 & 68.63 & 71.39 \\
\hline 6 & Chandigarh & 78.38 & 89.89 & 89.72 & 96 \\
\hline 7 & Chhattisgarh & 51.88 & 62.96 & 67.36 & 68.9 \\
\hline 8 & Dadra \& Nagar Haveli & 69.01 & 52.18 & 89.99 & 62.7 \\
\hline 9 & Daman \& Diu & 86.96 & 50.87 & 84.17 & 77.24 \\
\hline 10 & Goa & 77.21 & 69.03 & 94.91 & 77.96 \\
\hline 11 & Gujarat & 80.62 & 78.29 & 90.45 & 82.64 \\
\hline 12 & Haryana & 75.41 & 88.41 & 92.63 & 92.25 \\
\hline 13 & Himachal Pradesh & 74.93 & 86.08 & 92.8 & 93.56 \\
\hline 14 & Jammu \& Kashmir & 77.74 & 81.84 & 91.38 & 83.12 \\
\hline 15 & Jharkhand & 54.55 & 72.36 & 69.8 & 70.8 \\
\hline 16 & Karnataka & 79.15 & 80.97 & 96.39 & 87.6 \\
\hline 17 & Kerala & 78.91 & 30.89 & 92.87 & 54.55 \\
\hline 18 & Lakshadweep & 84.78 & 0 & 97.64 & 25.93 \\
\hline 19 & Madhya Pradesh & 63.21 & 75.93 & 85.35 & 82.34 \\
\hline 20 & Maharashtra & 81.6 & 87.58 & 95.36 & 91.15 \\
\hline 21 & Manipur & 16.35 & 57.14 & 65.74 & 70.4 \\
\hline 22 & Meghalaya & 69.81 & 76.66 & 79.9 & 80.34 \\
\hline 23 & Mizoram & 64.8 & 63 & 89.72 & 79.48 \\
\hline 24 & Nagaland & 58.29 & 72.24 & 94.38 & 76.52 \\
\hline 25 & NCT of Delhi & 71.72 & 91.04 & 91.28 & 96.04 \\
\hline 26 & Odisha & 48.94 & 57.49 & 64.33 & 59.04 \\
\hline 27 & Puducherry & 70.94 & 68.07 & 91.98 & 82.58 \\
\hline 28 & Punjab & 82.76 & 89.77 & 94.82 & 90.9 \\
\hline 29 & Rajasthan & 71.4 & 80.19 & 89.18 & 86.04 \\
\hline 30 & Sikkim & 83.38 & 94.19 & 91.99 & 92.12 \\
\hline 31 & Tamil Nadu & 66.42 & 70.02 & 85.17 & 74.94 \\
\hline 32 & Tripura & 43.37 & 53.06 & 63.96 & 53.45 \\
\hline 33 & Uttar Pradesh & 63.76 & 92.38 & 84.61 & 93.36 \\
\hline 34 & Uttarakhand & 77.87 & 88.24 & 93.1 & 92.9 \\
\hline \multirow[t]{2}{*}{35} & West Bengal & 58.56 & 67.14 & 70.66 & 66.83 \\
\hline & INDIA & 70.40 & 77.87 & 86.98 & 81.77 \\
\hline
\end{tabular}

HHs: Households

Source: Census of India-2001 \& 2011 
Table-2: Urban Latrine Facilities in 2011 (The Handbook of Urban Statistic 2016)

\begin{tabular}{|c|c|c|c|c|c|c|}
\hline S. No. & State / UT & Water Closet & Pit Latrine & Other Latrine & $\begin{array}{l}\text { Total HHs with } \\
\text { Latrines }\end{array}$ & No Latrine \\
\hline 1 & Andaman \& Nicobar Island & 86.80 & 0.20 & 0.10 & 87.10 & 12.90 \\
\hline 2 & Andhra Pradesh & 79.40 & 4.10 & 2.60 & 86.10 & 13.90 \\
\hline 3 & Arunachal Pradesh & 74.90 & 13.90 & 0.70 & 89.50 & 10.50 \\
\hline 4 & Assam & 71.00 & 21.00 & 1.70 & 93.70 & 6.30 \\
\hline 5 & Bihar & 63.40 & 4.60 & 1.00 & 69.00 & 31.00 \\
\hline 6 & Chandigarh & 87.00 & 0.50 & 0.10 & 87.60 & 12.40 \\
\hline 7 & Chhattisgarh & 58.70 & 1.10 & 0.40 & 60.20 & 39.80 \\
\hline 8 & Dadra \& Nagar Haveli & 80.30 & 0.70 & 0.30 & 81.30 & 18.70 \\
\hline 9 & Daman \& Diu & 84.20 & 1.10 & 0.10 & 85.40 & 14.60 \\
\hline 10 & Goa & 80.60 & 3.50 & 1.10 & 85.20 & 14.70 \\
\hline 11 & Gujarat & 85.20 & 2.10 & 0.40 & 87.70 & 12.30 \\
\hline 12 & Haryana & 80.50 & 7.70 & 1.70 & 89.90 & 10.10 \\
\hline 13 & Himachal Pradesh & 87.00 & 0.80 & 1.30 & 89.10 & 10.90 \\
\hline 14 & Jammu \& Kashmir & 68.50 & 4.30 & 14.70 & 87.50 & 12.50 \\
\hline 15 & Jharkhand & 64.70 & 1.80 & 0.60 & 67.10 & 32.80 \\
\hline 16 & Karnataka & 71.60 & 12.00 & 1.40 & 85.00 & 15.10 \\
\hline 17 & Kerala & 75.30 & 21.90 & 0.30 & 97.50 & 2.60 \\
\hline 18 & Lakshadweep & 97.20 & 0.50 & 0.00 & 97.70 & 2.30 \\
\hline 19 & Madhya Pradesh & 71.50 & 1.70 & 1.00 & 74.20 & 25.80 \\
\hline 20 & Maharashtra & 67.30 & 2.40 & 1.60 & 71.30 & 28.70 \\
\hline 21 & Manipur & 63.70 & 23.30 & 8.80 & 95.80 & 4.20 \\
\hline 22 & Meghalaya & 82.90 & 12.30 & 0.60 & 95.80 & 4.30 \\
\hline 23 & Mizoram & 80.90 & 17.20 & 0.50 & 98.60 & 1.50 \\
\hline 24 & Nagaland & 79.10 & 15.00 & 0.50 & 94.60 & 5.40 \\
\hline 25 & NCT of Delhi & 86.00 & 1.70 & 2.10 & 89.80 & 10.20 \\
\hline 26 & Odisha & 58.80 & 4.20 & 1.80 & 64.80 & 35.20 \\
\hline 27 & Puducherry & 81.10 & 0.60 & 0.30 & 82.00 & 18.00 \\
\hline 28 & Punjab & 85.60 & 6.80 & 1.00 & 93.40 & 6.60 \\
\hline 29 & Rajasthan & 73.70 & 5.40 & 2.90 & 82.00 & 18.00 \\
\hline 30 & Sikkim & 91.80 & 3.30 & 0.10 & 95.20 & 4.80 \\
\hline 31 & Tamil Nadu & 66.50 & 6.80 & 1.80 & 75.10 & 24.90 \\
\hline 32 & Tripura & 50.00 & 47.00 & 0.90 & 97.90 & 2.10 \\
\hline 33 & Uttar Pradesh & 77.20 & 2.90 & 3.00 & 83.10 & 16.90 \\
\hline 34 & Uttarakhand & 85.90 & 6.50 & 1.10 & 93.50 & 6.40 \\
\hline \multirow[t]{2}{*}{35} & West Bengal & 61.60 & 22.50 & 0.90 & 85.00 & 15.00 \\
\hline & INDIA & 72.60 & 7.10 & 1.70 & 81.40 & 18.60 \\
\hline
\end{tabular}

HHs: Households

Note: * Water Closet-Flush/Pour Flush Latrine connected to Piped Sewer/Septic Tank/Others

\# Other Latrines include night soil disposed into open drains and service latrines.

source: Census of India-2001

\section{Solid Waste Management}

There is a direct correlation between the rising urban demography and solid waste creation which makes municipal solid waste (MSW) management a humangeous task. This is among one of the priority areas under the smart city mission. Uncollected piles of solid waste is not only an environmental and health hazard but against the spirit of smart city too. Solid waste management for smart cities is both a challenge and an opportunity because it requires new alternatives and models to handle it. Smart cities globally are experimenting with new concepts. Central Public 
Health and Environmental Engineering Organisation's (CPHEEO)Manual of Municipal Solid Waste Management (2016) indicates that during 2014-15,1,43,449 tones per day (TPD) of MSW was generated in India with an average waste of $0.11 \mathrm{kilogram}(\mathrm{kg}) / \mathrm{capita} /$ day. Of the total 1,17,644 TPD approximately, 80 percent was collected. Only 32,871 TPD (22\%) was processed or treated. Besides, it also points out that segregation at source, collection, transportation, treatment, and scientific disposal of waste remains grossly inadequate which contributed to the urban mess.

\section{Solid Waste to Circular Economy: A Smart Approach}

Smart city Songdo has its own method of SWM. Benedict (2016) writes: "To make the city more sustainable, innovative waste management was developed: every flat in the city has a pneumatic trash pipe. Once residents of Songdo throw their domestic trash in this pipe, it will be supplied to a central waste processing centre by the underground system and recycled there." No doubt, the nature of technological intervention will determine the effectiveness of smart city. However, technological interventions should be an outcome of the conceptual models. The Circular Economy model for example may help redefine waste and design the system of its management in such a manner where nothing goes wasted rather comes back with new utility. The concept may be converted into interesting and effective model of sustainable development in India. Circular economy talks of shift of the whole consumption pattern from the 'cradle to grave' to a circular model. Ellen MacArthur Foundation's report on circular economy (2013) refers to the 'Linear to Circular' model wherein recycalability remains at the core of production itself. 'Take-make-dispose' (Ellen MacArthur Foundation, 2013) model of production and consumption is responsible for the large scale creation of waste. Therefore, solid waste management should also address the problem at the source which will help in finding smart solution. The model of circular economy is based on some simple principles. 'Design out waste' is one of them. The principle states:

"Waste does not exist when the biological and technical components (or 'nutrients') of a product are designed by intention to fit within a biological or technical materials cycle, designed for disassembly and refurbishment. The biological nutrients are non-toxic and can be simply composted. Technical nutrients - polymers, alloys, and other man-made materials are designed to be used again with minimal energy and highest quality retention.” (Towards the Circular Economy, 2013)

\section{Diagram 2: Circular Economy}

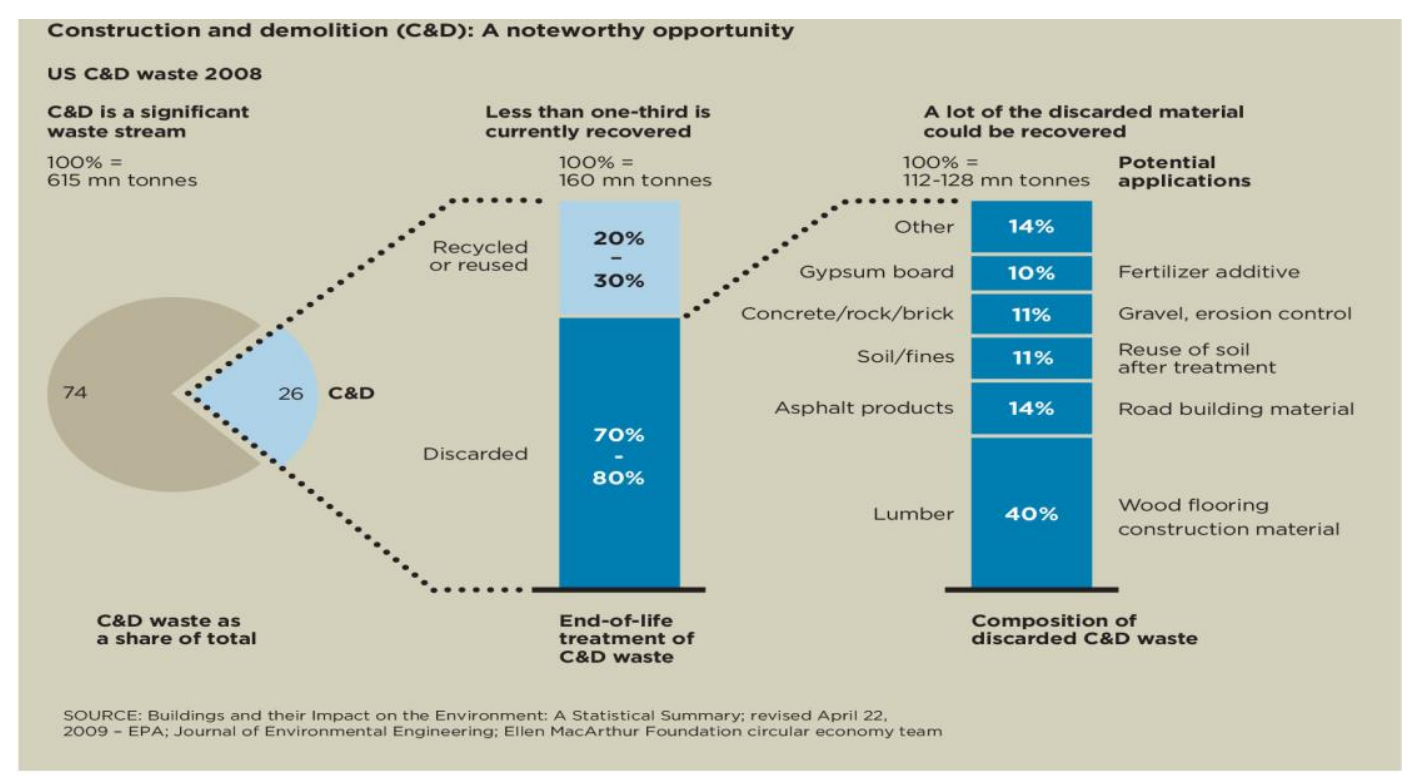

Source: Towards the Circular economy, 2013 
The rates of recovery for most of the materials after their first use is very high as compared to their first use. This adds up to the creation of solid waste of different kind in the cities. It's estimated approximately 65 billion tones raw materials were consumed by the global economy in 2010. It's likely to grow to about 82 billion tonnes in 2020 . Europe alone generated 2.7 billion tones of solid waste in 2010, out of which only 40 percent of that was reused, recycled, or composted and digested.

The circular economy thus offers two models to manage the biological and mechanical wastes which may be a useful holistic model for the solid waste management for smart cities. The conceptual diagram 2 of circular economy explains the possibility of reprocessing the waste for useful applications. For the consumption driven modern lifestyle the model of circular economy is worth considering. The model can very well integrate with the Swachch Bharat Mission meant for improving sanitation in India and through that to the Smart City Mission itself.

\section{Urban Transportation}

Creating efficient, environment friendly, safe and affordable urban mobility system is integral to smart city vision. Host of policy initiatives in recent years such as National Urban Transport Policy 2014, Atal Mission for Rejuvenation and Urban Transformation (AMRUT), Automotive Mission Plan (AMP2026), Make in India Scheme, Skill India programs and FAME (Faster Adoption and Manufacturing of Electric/Hybrid) India Scheme are expected to transform India's urban transport system into an efficient system over the next decade. The above policies will have to be aligned with the smart city mission. The varied modes of urban transport in India include man, animal to power driven vehicle options; all plying on the same road at the same time. Last mile connectivity which is rather poor at ths point of time will have to be looked into under the smart city mission.

India Transport Report - Moving India to 2032 (2014), estimates that from 10,375 bpkm (billion passenger kilometer) in 2011-12, it's likely to grow at the rate of 15 percent per annum to reach 168,875 bpkm by 2031-32. The aforesaid report also says that the population in the million plus cities has been increasing. As per the 2011 census, 468 urban class-1 agglomeration constitute 70 percent of urban population. As a result, the pressure on the existing public transport system is increasing. However, there has not been commensurating rise in the public transport system rather a decline. 1991 onwards there has been a six fold increase in the registered vehicles and the number has gone up from 21 million to 142 million. Number of two wheelers has gone up from 14 million to 102 million during the same period whereas the number of public buses has declined to 1.1 percent of the total registered vehicles from 11.1 percent in 1951. It's a clear indication of the inadequacy of public transport system and rising dependence on personal mobility options including two wheelers and cars. Its environmental fallout and impact on traffic condition are obvious.

\section{Smart Mobility}

The factors stated above thus necessitate designing mobility options. Masdar, the smart city in UAE which aims at attaining zero carbon emission, has designed Personal Rapid Transit (PRT) system which uses sustainably produced electricity to shuttle within the city. The PRT system works on a magnetic system which is embedded intoits concrete track. There is an overhead antenna that runs the length of the undercroft to provide wireless link between the PRTs and its computer system. This ensures zero carbon emission which is the USP of Masdar smart city. Besides, it also provides cars and buses run by electricity and biodiesel.

Acharya and Morichi (2013) explain the existing urban transport system of megacities as: "a combined result of dynamic interaction of institutions; the society's evolving need in mobility brought about by their changing physical, social, economic, and political environments; and the advancement in technology." The idea of smart city is an idea of change in which the socio-economic, spatial environment will be shaped by the technological interventions in order to make the cities sustainable. Smart sustainable cities will require sustainable urban transportation system too. In a comprehensive sense sustainable transportation system refers to the behavioral and socioeconomic aspects alongside new concepts viz. systems approach which analyzes the relationship between the part and the whole. Systems approach will help examine transportation in the context of economic, environmental and social systems and their interactive effects on development (TRB 1997). 
Smart city creates its own eco-system driven by ICT, design, technology, innovation and so on which deal with various aspects of modern urban life including smart mobility. Benevolo, etal. (2016) describe Smart City as: "a complex, long-term vision of a better urban area, aiming at reducing its environmental footprint and at creating better quality of life for citizens." They have tried to analyze the interconnectedness between smart mobility and smart city. Their concept of smart mobility includes environmental and economic aspect of mobility on the one hand and application of technology and people's behaviour on the other. Thus, smart mobility has to strike a balance between citizens' opinions about live ability in cities and quality of local public transport services as well. Giffingeret al.(2007) who define smart city as "a city well performing in a forward-looking way in economy, people, governance, mobility, environment, and living, built on the smart combination of activities of self-decisive, independent and aware citizens" also underscore the improved options of mobility as a key feature of smart city.

Hence, smart mobility turns out to be not just a new nomenclature in the smart city taxonomy, but an essential aspect of the whole concept itself .Robuste (2010) believes: "Urban mobility (UM) is undergoing a change of concept (mutation) and needs a re-engineering and systems approach to interact with city planning and ICT." Here the application of design's systems thinking approach which helps analyze the relationships between the larger set and its sub-sets may be immensely useful. Design intervention at this level may help in developing a sustainable model of mobility based on the synergetic relationship between part and the whole which is smart city and mobility. The concept of urban mobility itself has acquired new meaning. Table 3clearly explains the difference between the old and the new. The new concepts may help in designing smart and sustainable mobility solutions.

Table 3: Concepts of Sustainable Mobility Options; old and new

\begin{tabular}{l|l|}
\hline Old concepts & New concepts \\
\hline Functionalism & Sustainability \\
\hline Diffuse city (urban sprawl) & Compact city \\
Specialised land uses & Multifunctional city \\
\hline Direct costs of operation & Ecological accounting \\
Commuting & Cloud-shaped mobility \\
\hline Required (household-based) mobility & Daily mobility \\
\hline Transport policy & Mobility policy and right to accessibility \\
Long distance & Proximity \\
\hline Longitudinal use of streets & Cross-street use
\end{tabular}

Source: Noy, P. (2001), Mobility is one of the most important problems of the country. Public Transport Promotion Association, Barcelona (in Catalan).

\section{Urban Policies in India}

Smart city Mission in a way is a response to the decades of neglect that Indian cities had to face. The imperative of taking a quantum jump is due to the fact that the policies of urban development have been rather inadequate and not $\mathrm{n}$ sync with time. The first five year plan (1951-56) was mainly concerned with housing, rehabilitation of refugees in Delhi, Mumbai, Kolkata, Ahmedabad and cities of Haryana and Punjab states. Although Chandigarh as a modern planned city designed by Le Corbusier was set up during this period, nonetheless, the model was not replicated elsewhere. The plan looked at slum clearance 'a national problem' and 'disgrace to country'.

The 2nd Five Year Plan (1956-61) recognized "rise in land values, speculative buying of lands in the proximity of growing towns, high rentals and the development of slum areas" as common syndrome affecting most of the cities. The emphasis of the Plan was thus on regional planning and preparation of master plans. Besides, there was also some stress on constructing housing for low income groups. As a result, the first Town and Country Planning legislation was enacted and institutions to prepare master plan were set up in many states. Further, the Slums Areas 
(Improvement and Clearance) Act was passed in 1956. As per the Act a slums meant: "any area(where) buildings...(a)are in any respect unfit for human habitation, or (b) are by reason of dilapidation, over-crowding, faulty arrangement and design of such buildings, narrowness or faulty arrangement of streets, lack of ventilation, light or sanitation, or any combination of these factors, are detrimental, to safety, health or morals" (GoI, Slum Act).The Master Plan based urban development began during the $3^{\text {rd }}$ Plan Period (1961-66). Urban Development Authorities viz. Delhi Development Authority (DDA), Mumbai Metropolitan Regional Development Authority (MMRDA), Madras Metropolitan Development Authority (MMDA), were set up during this period. The master plans were meant to ensure systematic development of cities driven by stringent spatial segregation between areas for housing, business and industries. However, the plans remained oblivious of the common mixed-land use was pattern in India. Despite all such efforts land prices kept increasing and consequently slums kept increasing.

The $4^{\text {th }}$ Plan period (1969-74) aimed at balanced urban growth and decongesting big cities like Delhi, Kolkata, Bombay and Madras by diverting populations to smaller urban centers. It emphasized the need to set up small towns having their own model for economic sustainability. The Plan recommended: (i) the optimum use of land (ii) availability of land for the weaker sections (iii) preventing concentration of land ownership, its rising value and speculative pricing and finally (iv) allowing use of land as resource for financing city's development plans. HUDCO the institution for financing urban jousting was set up during the same period.

The subsequent Plans also mainly focused on creating the institutional set ups of various kind to tackle the issues of urbanization. However, what was missing was the approach to first accept it as an opportunity of growth and then to prepare a roadmap or blueprint for future development. Most of the policy initiatives were largely remedial rather than being futuristic.

The first significant endeavor to augment the capabilities of urban governments came through the constitutional amendment of 1992 which allowed state governments to decentralize several responsibilities to municipal bodies. It included among other land-use, economic development, water, roads and poverty alleviation etc.(The Evolution of National Urban Policies A Global Overview, 2014).

The first major urban program for urban rejuvenation Jawaharlal Nehru National Urban Renewal Mission (JNNURM) was launched in 2005. It had wide scope. Through this program it was expected to get investment of USD 24 billion for 67 cities over a period of seven years. It was later extended by another two years. To upgrade the slums and provide basic amenities Rajiv Awas Yojana (RAY) was launched in 2013 for a period of 10 years. Both the programes however are hindered by local capacity constraints and lack clarity as to how the support will be distributed between cities and towns (Chaplin, 2011; Kundu, 2014).

In the the era of market economy Indian government is now trying to bring lots of reforms in its economic policies. They influence both urbanization and urban policies. Cities are being regarded as growth engines of economy. So the economic and administrative autonomy of cities will be essential to improve their performance. The growth disparity among Indian cities is a reflection of ill-conceived, shortsighted policies of urban development. However, the emerging new middle class nurtures global aspirations and want to live in global cities. Emergences of Bangalore, Gurgaon are cases in point. The aspirations to enjoy status of "global city" are now influencing India's urban planning policies (Dupont, 2011).

\section{Smart City Mission}

India's present smart city mission has evolved from the earlier visions for urban future. While technology and design, at spatial, product, communication and systems level, will drive the smart city mission, but the issues it hasto address will remain one of sustainable urban development. The Planning Commission Steering Committee Report (2012) on India's urban futuredealing with sustainable urban development envisioned a slum free city having "less than 10 percent urban poor, 100 percent access to water and sanitation, more than 50 percent share of public transport and 75 percent of new commercial buildings to be energy efficient." 


\section{Diagram 3: Constituents of Urban Future}

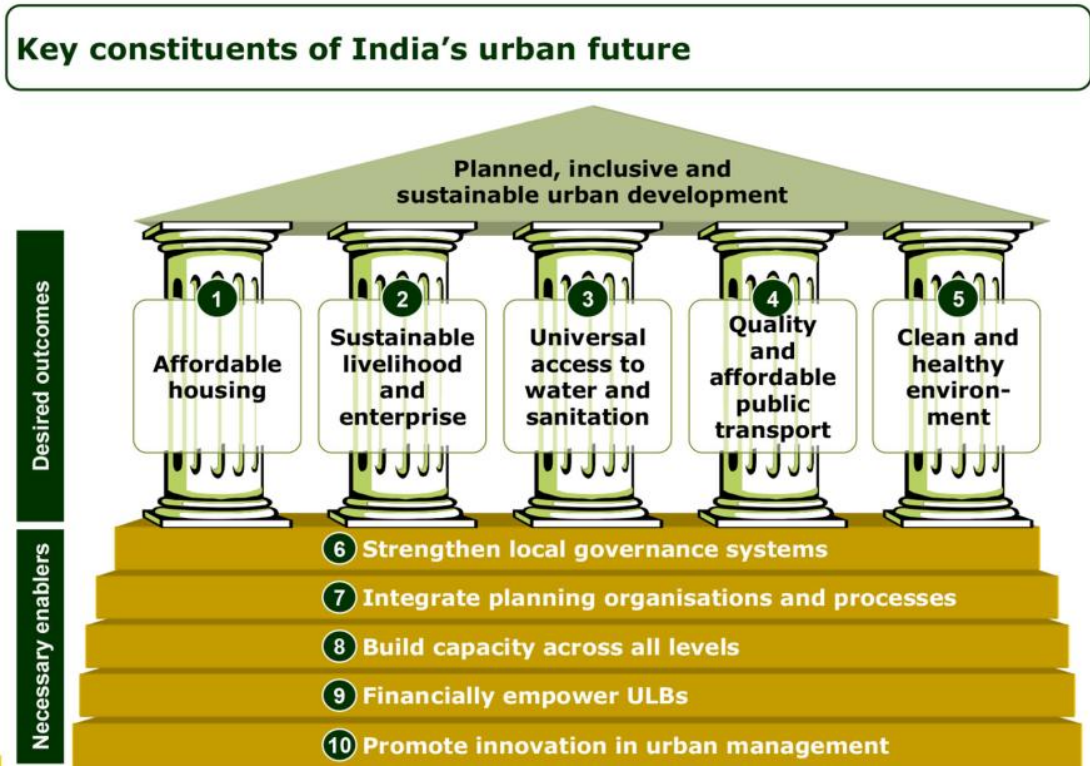

Source: Report of the Steering Committee on Urbanization. Planning Commission (2012-17) http://planningcommission.nic.in/aboutus/committee/strgrp12/strrep_urban0401.pdf

The challenges for smart city largely remain the same. According to The Smart City Mission Strategy of the Government of India (2017): "The strategic components of area-based development in the Smart Cities Mission are city improvement (retrofitting), city renewal (redevelopment) and city extension (greenfield development) plus a Pan-city initiative in which Smart Solutions are applied covering larger parts of the city." The focus of India's Smart Cities Mission remains city improvement (retrofitting), city renewal (redevelopment) and city extension (Greenfield development). These cities are meant to rejuvenate the ailing urban system, improve infrastructure, quality of life and achieve sustainable and inclusive development. Incremental addition of technology, design and IT-led smart features are envisaged to transform them into modern world-class cities eventually. Indian cities which are home to approximately 38 million people, are big, dense and overburdened and yet expected to become smart, efficient and sustainable. The rising population and urban migration are putting tremendous pressure on India's megacities, over 7000 towns and close to 1500 urban agglomeration. They desperately need improved infrastructure and basic amenities such as water, sanitation, sewage, road, transportation among other. Environmental sustainability and urban resilience are among the equally important concerns.

\section{Smart City Models}

The concept of smart cities arises both curiosity and expectations. This technology driven urban design where systems are run and regulated by apt and efficient application of technology are creating new models of smart urbanism. Songdo in South Korea and Masdar in the UAE; the two new smart cities are the cases in point which have been built afresh. However, smart interventions are also being made in pre-existing cities like Amsterdam which aims at reducing $\mathrm{CO}_{2}$ emission to the level of $40 \%$ by 2025. Apart from this, it also seeks to promote economic growth making smart application of ICT and changing its citizens' behaviour towards more sustainable lifestyle. It's planning to convert its ports into smart ports, introduce smart shipping traffic to prevent traffic jams on waterways, green energy playground for the families so that kids could be incentivized to play more. London Smart City vision includes use of smart grid technology for better use of energy and water. It plans to use data and technology to develop new markets for London's waste that brings efficiencies and scale to the segregation and utilization of waste as a resource. Its smart intervention also aims at using 3D visualization to minimize unnecessary digging of the road by different agencies. However, India's own conceptual framework for smart cities needs to look up to the contemporary global benchmark and also consider the exclusive socio-economic priorities of its own cities based on the data of India's urban challenges. Unlike the newly developed models of smart city like Songo, Masdar, 
Plan IT Valley (Portugal) and other, India's majoarchallenge lies in making smart interventions in urban retrofitting. At present Lavasa is probably the only (private) city which has semblance of smart city and the one which is modeled on the principle of new (sustainable) urbanism in India.

\section{Sustainable Urbanism and Smart City}

The ever rising urban population is bringing the issue of sustainable urbanism for serious discussion. Cities not only have to be environmentally sustainable but socially and economically as well. Urban sustainability means evolving a harmonious eco-system of sustainable mobility devices, energy, water, housing, landscape etc. However, this ecosystem has to be in harmony with the needs of people and their impact on resources. Sustainable urbanism is at the core of smart cities everywhere including India. It cannot overlook the concept of sustainable development which means "development which meets the needs of the present without compromising the ability of future generations to meet their own needs" (World Commission on Environment and Development 1987: 43). Thus, the whole approach of smartness ultimately depends on the fact that how sensibly the optimal use of resources has been made.

Smart city in India and elsewhere are expected to create sustainable and efficient urban clusters which can offer better quality of life to the city dwellers. Sustainable urbanism in itself is a holistic approach towards sustainability and urban design which includes all the processes that shape the form and function of the built environment in its full complexity - infrastructures, land developments, built landscapes, social networks, systems of governance and economics and facilities (Ejigu \& Haas, 2011). It includes creating walkable mixed use urban environments that allow and encourage walking and bicycling; designing public transit and transport systems etc. The agenda of sustainable urbanism has many things in common with the concept of smart city. Like smart city, sustainable urbanism also deals with integrating various means of transportation, efficient land use, building sustainable neighborhoods, housing, walkable neighborhoods, universal accessibility, linking human life to nature, waste treatment, smart buildings and energy systems among other. However, the reason they are not used synonymously is because while sustainable urbanism remains the objective, smart city indicates the required intervention of technology, design and systems innovation.

From the urban planning perspective (including that of smart cities) sustainable urbanism has to be a normative planning model setting broader guidelines while sustainability or sustainable development have to remain as a governance objective (Rapoport, 2014). Policymakers have to look at urban planning from the perspective of sustainable urbanism both for the existing and new cities. Lehmann (2016) observes that:

"urban developments are rarely purely the result of design considerations; rather they are shaped by economic forces, the evolution of policies, and a range of invisible forces such as land-use regulations, codes for floor space ratios and economic power structures."

Smart cities will not be exempt from these factors. Indian cities may be different from each other in terms of their size, original or proposed design, natural resources and landscape but they require something in common which include.Cities require efficient integration of transport, energy; integrated land-use, water and waste planning; reengineering infrastructure, retrofitting the existing city and gentle densification; balancing compact city development at denser transport nodes with new public green spaces (Lehmann, 2016). Use of ICT, electronic sensors, fiber optics, mobile telephony, network engineering, real time monitoring and data collection and dissemination which drive the smart cities will have to be effectively used to provide answer to India's urban challenges. Sustainable urbanism, which smart cities will be expected to achieve will eventually include balancing environmental, economic and social objectives; all quite crucial from the Indian perspective where the nature of society and cities both are so heterogeneous.

\section{Design and Technology Intervention}

From design perspective, smart city is a meta-system of sub-systems. It has social, cultural, economic, spatial dimensions. It incorporates people, various operating systems and infrastructure. IBM identifies them as an interaction of planning and management, infrastructure and people. Like other public policies, the efficacy of urban policies also lie in improving service delivery by creating better synergy between them. Planning and management uses longstanding visions developed through comprehensive data analysis. It's used in management of daily affairs of the city for its safety and security and ease of doing business. Infrastructure include basic urban services viz. 
roads, mass transit and mobility systems, energy, efficient housing, water and sanitation, robust IT set up among other. The infrastructure and its management are directed towards people so that their livelihood, education, healthcare and other essential needs are provided seamlessly. Intervention of technology, design and innovation at various levels are key to the very concept of smart city. Despite enormous scope of intervention from the product to systems level, neither the role of design has been clearly articulated in the smart city mission, nor the design community itself has envisioned its own agenda and creative solutions for India's upcoming smart cities. So far design intervention in cities has not moved beyond the architectural and spatial domains, whereas smart cities would require integration of urban systems, technology and innovation. In other words, design intervention in smart cities will require integration of people, infrastructure and planning as the diagram 4 explains.

\section{Diagram 4: Key Elements of Smart City}

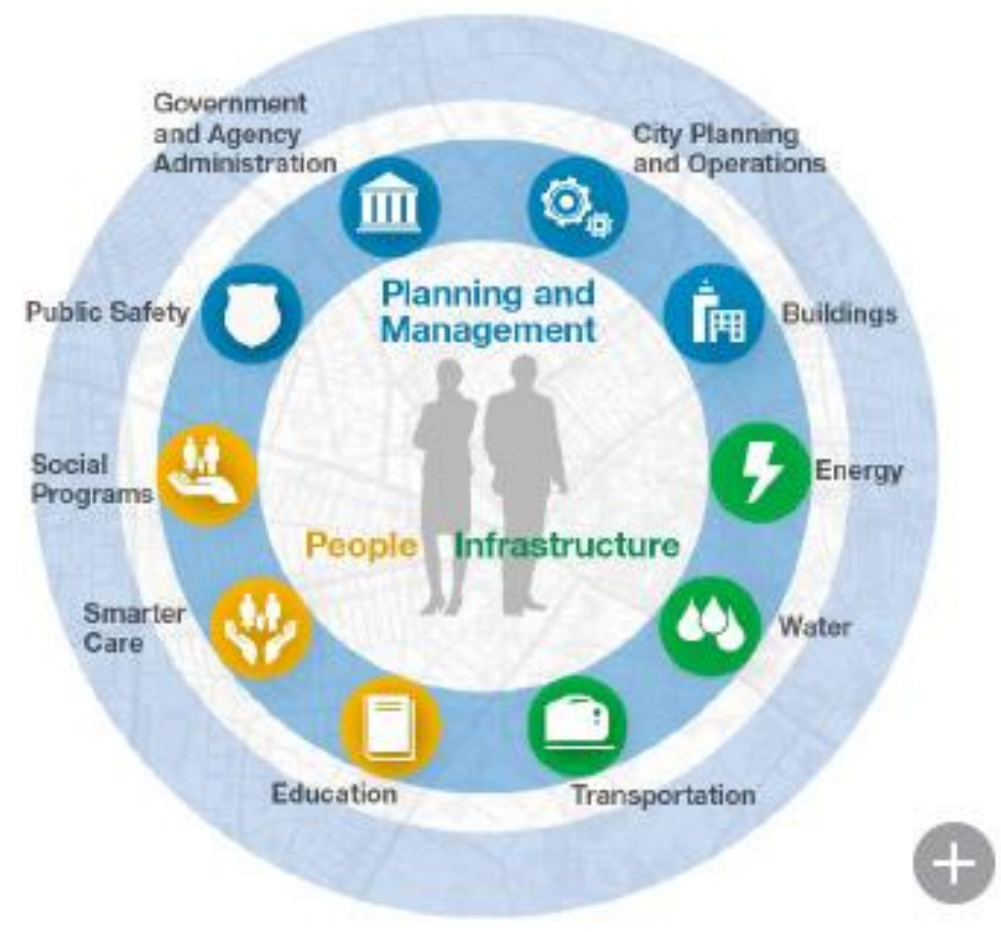

Source: IBM, Smarter Cities, New cognitive approaches to long-standing challenges.

\section{Conclusion}

In India smart cities are expected to transform urban systems to their highest level of efficiency through technology, design, innovation and policy reforms so that with optimum utilization of resources sustainable urbanization could be achieved. The premise on which the concept of smart cities rests indicates that in the light of the rising challenges of urbanization systems governing the cities need revolution rather than evolution. For example, communication in Indian cities both in terms of transport of people and data need radical improvement. Urban development and ecological imbalance are big concerns. Delhi, which is the fifth most populous city in the world having an estimated population of 17.8 million (2014), is also one of world's most polluted cities for example. The Air Quality Index (AQI) of Delhi remains in the range of 300 which is considered very unhealthy and hazardous. Vehicular pollution is the largest contributor to this mess followed by industrial pollution. As per the data of Delhi Government 847 million motor vehicles (of all types) were registered in Delhi till March 2015. As such, the city requires urgent smart interventions to improve the public transport system so that problems like air pollution, congestion, road rage etc. can be reduced to the limit of human tolerance.

The rising urbanization of India poses both enormous challenges and opportunities. Smart city is a timely response to that. Critics of the idea of smart city believe that cities have always been smart and their intelligence resides in the people (Greenfield, 2013). The contemporary semantics of smart cities however explain different approaches of 
looking at them from different perspectives viz. resilience, business, growth of citizens or services within an urban environment among other. The optimism of 'the smart city' is a kind of rhetorical move within a much larger space of potential (Greenfield 2013). Most of our present urban problems have been created by technology itself by enabling large scale production, consumption, lifestyle aspirations, concentration of economic activities at few places and so on. Now technology itself is trying to innovate smart processes to clear the mess. But unless technological innovations are aligned with social innovations India's urban chaos will not improve much. Social innovation means implementation of new ideas including technology, design, products, services and models in order to meet social needs. It must go alongside the technological innovation, which has overpowered the idea of smart cities. Social innovation will help in the identification of emerging or inadequately met social needs of the Indian cities, development of new solutions and analyzing the efficacy of the new solutions. A successful model of smart city in India will be one which will use technology (including ICT) to empower people to innovate new ideas to achieve sustainable urbanism as well as sustainable development goal.

\section{References}

1. Acharya, Surya Raj. \&Morichi, Shigeru. (Eds.) (2013). Evolving Concepts in Urban Transport. Springer, $X I I$. Retrieved on $15^{\text {th }}$ April 2017 from file://C:/Users/Bhole_000/Desktop/9783642297427-c1.pdf

2. Ahluwalia, I.J., \&Mohanty, P.K. (2014). Planning and Market for Urban Development in India. (pp. 69). In Ahluwalia, I.J., \&Mohanty, P.K. (Eds.) Urbanisation in India, Challenges, Opportunities and way Forward. (pp. 69). Delhi: Sage Publications.

3. Batra, Lalit. (2009). A Review of Urbanisation and Urban Policy in Post-Independent India (Working Paper). Delhi: Centre for the Study of Law and Governance Jawaharlal Nehru University, New Delhi.

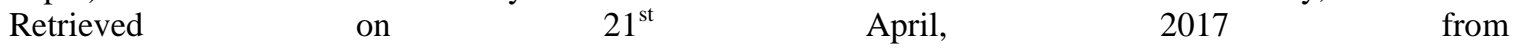
http://www.jnu.ac.in/CSLG/workingPaper/12A\%20Review\%20of\%20Urban\%20\%28Lalit\%20Batra\%29.p df

4. Benevolo, C. ,Dameri, R. P. and D’Auria, B. (2016). Smart Mobility in Smart City: Action Taxonomy, ICT Intensity and Public Benefits. Springer International Publishing. https://doi.org/DOI 10.1007/978-3-31923784-8_2

5. Benedikt, Olesya. The Valuable Citizens of Smart Cities: The Case of Songdo City. Graduate Journal of Social Science April 2016, Vol. 12, Issue 2, pp. 17-36. Retrived on 10 ${ }^{\text {th }}$ April 2017 from http://gjss.org/sites/default/files/issues/chapters/papers/GJSS\%20Vol\%2012-2\%201\%20Benedikt_0.pdf

6. Bholey, Mihir. (2016). India's Urban Challenges and Smart Cities: A Contemporary Study. Scholedge International Journal of Business Policy \& Governance. Vol.03, Issue $03, \quad 21$. [http://www.thescholedge.org/journals/]

7. Chaplin, S. (2011). Indian cities, sanitation and the state: the politics of the failure to provide, Environment and Urbanization, vol 23, No 1, pp. 57-70.

8. Dupont, V. (2011). The dream of Delhi as a global city, International Journal of Urban and Regional Research, vol 35, No 3, pp. 533-554.

9. Ejigu, Alazar. \& Haas, Tigran. (2011). Contextual Modernism and Sustainable Urbanism as New Housing Strategies - A way for better understanding the phenomena of concentrated poverty. Presented at the Enhr Conference 2011, Toulouse. Retrieved on 24t April, 2017 from http://www.enhr.net/documents/2011\%20France/WS10/Haas\%20and\%20Ejigu-V3-WS10.pdf

10. Giffinger, R., Fertner, C., Kramar, H., Kalasek, R., Pichler-Milanović, N., Meijers, E. (2007). SmartCities: Ranking of European Medium-Sized Cities. Centre of Regional Science (SRF). ViennaUniversity of Technology

11. GoI (Undated) Slum Act, http://www.indianrailways.gov.in/RPF/Files/law/ BareActs/slumareas1956act.htm

12. Greengfield, A., (2013). This is Part I of The city is here for you to use: 'Against the smart city'. New York Do.

13. India Transport Report - Moving India to 2032. (2014) Deb, Sandip (Ed.) Delhi: Routledge. Retrived on $11^{\text {th }}$ April 2017. http://planningcommission.nic.in/reports/genrep/NTDPC_Vol_01.pdf

14. Kundu, A. (2014). India's sluggish urbanization and its exclusionary development', in McGranahan, G. and G. Martine, eds. Urban Growth in Emerging Economies, London: Routledge.

15. Lehmann, Steffen. (2016). Sustainable urbanism: towards a framework for quality and optimal density? Springer Open, 2:8. https://doi.org/DOI 10.1186/s40984-016-0021-3 
16. Marshall, Stephen. (2012). Sustainable Urbanism in Evolution. In Tigran Haas (Ed.) Sustainable Urbanism and Beyond. (pp. 59). New York: Rizzoli International Publication.

17. Ministry of Urban Development, Government of India. (2017). Smart Cities Mission (Government Report). Retrieved on $21^{\text {st }}$ April, 2017 from http://smartcities.gov.in/content/innerpage/strategy.php

18. Paul, Samuel. (2010). Urban Infrastructure and Governance. In Ramesh, et.al. (Eds.) Urban Growth and Governance in India an Overview. (pp. 3) London: Routledge.

19. PWC. (2015) Making cities smartand sustainable. Retrieved on Feb. 21, 2017, from https://www.pwc.in/assets/pdfs/publications/2015/making-cities-smart-and sustainable.pdf

20. Rai, Nishith\& Singh, A.K. (2010) New Dimensions of Urban Management in India (pp 164). New Delhi: Serials Publications.

21. Rapoport, E. R. (2014, September). Mobilizing Sustainable Urbanism: International Consultants And the Assembling of a Planning Model. University College London, London. Retrieved on $21^{\text {st }}$ April, 2017 from:http://discovery.ucl.ac.uk/1449528/1/Rapoport_Mobilizing\%20Sustainable\%20urbanism\%20final.pdf

22. Robusté, Francesc. (2010). The Future of Transport in Urban Areas. European Parliament. Retrieved on $15^{\text {th }}$ April, 2017 from http://www.europarl.europa.eu/RegData/etudes/note/join/2009/431580/IPOLTRAN_NT(2009)431580_EN.pdf

23. Shaw, Annapurna. (2012). Indian Cities. (pp. 1-2). New Delhi: Oxford University Press.

24. Swachh Bharat Mission Municipal Solid Waste Management Manual Part I: An Overview (2016) Central Public Health and Environmental Engineering Organisation (CPHEEO) Ministry Of Urban Development. Retrived on $11^{\text {th }}$ April 2017 http://moud.gov.in/pdf/57f1e55834489Book03.pdf

25. The Handbook of Urban Statistics 2016. Govt. of India Ministry of Urban Development. Retrived on $10^{\text {th }}$ April, 2017 from http://www.indiaenvironmentportal.org.in/files/file/handbook\%20of\%20urban\%20statistics\%202016.pdf

26. The Planning Commission: Approach to the $12^{\text {th }}$ Plan. 'The Challenges of Urbanization in India.' Retrived on $30^{\text {th }}$ March, 2017 from http://12thplan.gov.in/12fyp_docs/17.pdf

27. Planning Commission, Govt. of India. (2012). Report of the Steering Committee on Urbanisation (Twelfth Five Year Plan 2012-2017). Retrieved on 24 ${ }^{\text {th }}$ April 2017 from http://planningcommission.nic.in/aboutus/committee/strgrp12/strrep_urban0401.pdf

28. The World Bank. (2015) Leveraging Urbanization in India. Retrieved on Fe. 21, 2017 fromhttp://www.worldbank.org/en/country/india/brief/leveraging-urbanization-india

29. Towards the Circular Economy. (2013) Ellen MacArthur Foundation. Retrived on $10^{\text {th }}$ April 2017 https://www.ellenmacarthurfoundation.org/assets/downloads/publications/Ellen-MacArthur-FoundationTowards-the-Circular-Economy-vol.1.pdf

30. TRB (1997) Toward a sustainable future; addressing the long-term effects of motor vehicle transportation on climate and ecology. National Academy Press, Washington, DC

31. Turo, Ivan. (2014). The Evolution of National Urban Policies A Global Overview. UN Habitat. Retrieved

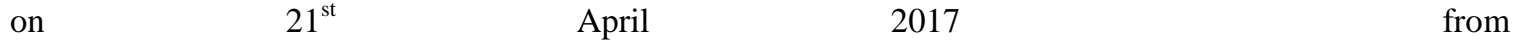
http://www.citiesalliance.org/sites/citiesalliance.org/files/National\%20Urban\%20Policies.pdf

32. UNO. (2016). Sustainable Development Goals: 17 Goals to Transform our World. Retrievedon $19^{\text {th }}$ Feb. 2017 from http://www.un.org/sustainabledevelopment/cities/

33. World Commission on Environment and Development (1987) Our Common Future, Oxford: Oxford University Press. 